\title{
Low-intensity laser efficacy in postoperative extraction of third molars
}

\author{
Eficácia do laser de baixa intensidade no pós-operatório em exodontia de terceiros molares
}

Tiago Nascimento MILETO'

Fabiano Goulart AZAMBUJA'

\begin{abstract}
The search for means that enable a better quality of life for postoperative patients should be incessant. The surgical extraction of third molars can result in potential complications such as pain, swelling and trismus, along with discomfort in the recovery phase. Therefore, this narrative review was to analyze, from systematic reviews and randomized clinical trials, the use of low level laser therapy as influencer the clinical state after third molar surgery. Scientific articles were searched through PubMed and Science Direct database. In spite of the evaluated studies have cited the effectiveness of laser therapy such as tissue repair, anti-inflammatory and analgesic, variety of analysis models and diversity of dosimetry leaves a gap on their true efficacy. Based on the research conducted, we suggest the adjuvant use of diode laser GaAlAs with 810 $\mathrm{nm}(\lambda), 100 \mathrm{~mW}$ constant power and $4 \mathrm{~J} / \mathrm{cm}^{2}$ of energy, intra and extra oral form at least three sections to minimize possible occurrences of third molar surgery.
\end{abstract}

Indexing terms: Low-level light therapy. Molar third. Postoperative complications. Surgery, oral.

\section{RESUMO}

A busca por meios que possibilitem uma melhor qualidade de vida pós-operatória aos pacientes deve ser incessante. O procedimento de exodontia de terceiros molares pode resultar em possíveis complicações, tais como dor, edema e trismo, juntamente com o desconforto na fase de recuperação. Dessa forma, esta revisão narrativa procurou analisar, a partir de revisões sistemáticas e estudos clínicos randomizados, a utilização da terapia a laser de baixa intensidade como influenciador do quadro clínico após cirurgias de terceiros molares. Os artigos científicos foram pesquisados através do banco de dados PubMed e Science Direct. Apesar dos estudos avaliados citarem a efetividade da laserterapia, como reparador tecidual, anti-inflamatório e analgésico, a variedade de modelos de análise e diversidade de dosimetrias deixa uma lacuna sobre sua verdadeira eficácia. Com base na pesquisa realizada, sugerimos a utilização adjuvante do laser diodo GaAlAs com 810 nm ( $\lambda$ ), 100 $\mathrm{mW}$ de potência constante e $4 \mathrm{~J} / \mathrm{cm}^{2}$ de energia, de forma intra e extraoral em pelo menos três sessões para minimizar as possíveis ocorrências da cirurgia de terceiros molares.

Termos de indexação: Terapia a laser de baixa intensidade. Dente serotino. Complicações pós-operatórias. Cirurgia bucal.

\section{INTRODUCTION}

The surgical extraction of third molars (SETMs) is a habitual procedure in dental practice, practiced mainly by maxillofacial surgeons. Although usual, the removal of these teeth may present possible complications in the postoperative phase, even when the proper recommendation and planning are employed. In the transoperative phase, the well employed technical surgery and the meticulous perioperative care can minimize the frequency of complications and limit its gravity'.

In general, among the probable complications post third molars extraction, we can mention alveolitis, bleeding, infection, pain, swelling, trismus, damage to the inferior alveolar nerve, bone fracture, oroantral communication, periodontal problems in surrounding teeth and teeth displacement to noble anatomic spaces ${ }^{2}$. The knowledge of these conditions ought to be well elucidated by the dental surgeon, allowing the identification and counseling to high-risk patients, and the management of the conditions in the proper way ${ }^{1}$.

In this context, the American Association of Oral and Maxillofacial Surgeons (AAOMS) advocates the preservation of evidence that grounds the dental practice. The recommendation of this entity focuses on the use of pertinent scientific data, with each case evaluated

\footnotetext{
${ }^{1}$ Universidade do Extremo Sul Catarinense, Faculdade de Odontologia. Av. Universitária, 1105, Criciúma, SC, Brasil. Correspondência para / Correspondence to: TN MILETO. E-mail: <tmileto@gmail.com>.
} 
individually when considering the treatment options ${ }^{3}$. Besides the well-established conventional therapies, the low-level laser therapy (LLLT) comes as a support and not as a substitute, with the goal to help in the reestablishment of the biological balance, resulting in a more orderly and sometimes faster cure ${ }^{4}$.

Thus, the goal of this article was to comprehend the mechanism, use and proper designation of the LLLT as an influencer of the clinical picture in the postoperative phase in SETMs, as well as the formulation of a usage protocol for surgeries in a University Dental Clinic in Santa Catarina.

\section{METHODS}

The present narrative review aimed to evidence, through systematic reviews and randomized clinical studies, the use of the low-level laser therapy in the recovery of patients submitted to these surgeries. Considering the theme representativeness in the dental field, the research was done with publications from 2000 to the present moment. Papers with prior publication to this period were not applied, taking in consideration that the subject is recent, except for the publications considered indispensable for the theoretical foundation.

The sources for the literature review were electronic databases, such as PubMed and Science Direct. The databases were studied with the use of the following terms in English: "Dentistry", "Low-Level Laser Therapy", "SoftLaser Therapy" and "Third Molar Surgery Complications"; and in Portuguese: "odontologia", "laser de baixa intensidade", "laserterapia", "exodontia de terceiros molares" and "complicações pós-cirúrgicas".

\section{RESULTS}

Laser is the light amplification by stimulated emission of radiation and its used was promoted aiming the action over the biological tissue ${ }^{5}$. Historically, the first successfully developed laser was from Theodore Maiman in 1960, with the ruby laser that was designed to emit in the visible red band ${ }^{6}$. Shortly afterward, in 1971, Mester and collaborators ${ }^{7}$ presented, in experimental studies with mice, the irradiation benefits of this kind of laser in the healing of wounds ${ }^{7}$. There are two types of laser, the highlevel ones and the low-level ones, being this one signaled as therapeutic for the resulting cell photoactivation ${ }^{4}$.

The therapeutic effectiveness promoted by light interaction is already elucidated by literature, although there is a lack of further development on how the laser energy acts on the organism cell levels and what the irradiation adequate parameters for the several indications ${ }^{8}$. In the last decades, the use of LLLT has increased as a non-pharmacological adjunct to the treatment with low collateral index ${ }^{8}$. In an in vitro study about the use of this kind of treatment to oral neoplasms, it was pointed that the therapy is known for its efficiency with pain reduction, wound healing and inflammation, and has also been under investigation for neurodegenerative disorders, strokes and traumatic cerebral injury 9 .

Laser is a light (electromagnetic radiation) that differs from conventional luminous sources, presenting certain special properties. Monochromaticity is the emission of photons with the same wavelength $(\lambda)$, same frequency or color. The exit power variability of the equipment can be obtained with the same wavelength, there being devices that emit in the red light from 10 to 100 milliwatts (mW). Coherence is laser's most important characteristic, where a very wavelength with equal direction propagates in a periodic and ordered way. Collimation represents the little divergence of the light beam direction ${ }^{5,10}$. The functioning regime or emission types translate the different ways of behavior according to time, where certain choice will demand a specific application, with two types: the continuous emission ones (cw), which remain on (constant exit power) and the pulsed regime ones (pw), which have oscillating exit power, that goes from a maximum value (peak power) until zero within a determined time (time length) (Figure 1) ${ }^{5}$.

The laser therapy action mechanisms involve the process of bio-stimulation in a molecular level9,11. In a cell level, studies evidence that the laser beam penetrates in the interior of the tissue where it is absorbed by chromophore molecules (light absorbers) that generate the increase adenosine triphosphate quantities (ATP), accelerating the metabolism an producing a physiological response ${ }^{12}$.

As in any other treatment, the use of laser therapy needs to be determined within important parameters, following physical and clinical factors for the obtainment of good results. The so-called irradiation parameters or dosimetry is the wavelength, power and energy density (ED). The wavelength or laser type ought to be specific for each treatment, although there is not a range of studies with representativeness to define the best type for each dysfunction ${ }^{5}$.

Even so, literature presents the different active means: the red emission laser $(\boldsymbol{\lambda}=630$ to $690 \mathrm{~nm}$ ) indicated 
for ulcers, herpes and open wounds healing; the near infrared types (over $700 \mathrm{~nm}$ ), like the gallium arsenide and aluminum diode laser (GaAlAs, $\lambda=790$ to $830 \mathrm{~nm}$ ) which is used for analgesia, swelling, tendinitis, nerve regeneration and chronic ulcers, and the gallium arsenide laser (GaAs, $\lambda=904 \mathrm{~nm}$ ) indicated for the treatment of sports morbidity, postoperative pain and swelling/edema (Figure 2) $)^{5}$. Moreover, helium neon gas $(\mathrm{HeNe}, \lambda=632,8$ $\mathrm{nm}$ ) and indium gallium arsenic phosphate (InGaAIP, $\lambda=$ $633 \mathrm{~nm}$ ) are mentioned, both indicated for wounds repair 4 .

Laser power is important to establish the calculus of the energy density to be administrated, from the average power, either from an equipment with pulsing or continuous regime. According to American Association of Physicists in Medicine (AAPM) ${ }^{5}$ the radiant power is the same as the electromagnetic radiation emitted, transmitted or received, with the watt $(\mathrm{W})$ as the unit used according the international system of units. Other descriptors for the laser therapy dose are the exposure time and the energy density (Figure 3$)^{5}$, with the latter considered by literature as the relation between the administrated laser energy and the irradiated surface, expressed in joules by square centimeter $\left(\mathrm{J} / \mathrm{cm}^{2}\right)$. The laser photo-activation does not occur exclusively in the region of placement of the ray beam, yet in a distribution area around it, in a tridimensional way ${ }^{4}$.

Currently many LLLT machines perform the calculus directly, with the necessity for the professional simply to insert the ED, which automatically results in the exposure time in relation to the power and the irradiated area, although some machines do not show the adequate dosimetry ${ }^{4}$.

The low-level laser therapy is internationally accepted as cell bio-modulator, used to reach ideal therapeutic effects, acting in the reduction of the pain response, with anti-inflammatory effects, stimulating local microcirculation and wounds repair, promoting a rapid recovery, which brings better quality of life to the patient ${ }^{11}$. Furthermore, its therapeutic effects restore the neural function post damage and improve the remodeling bone repair ${ }^{13}$.

The postoperative conditions of the surgical extraction of third molars such as pain, swelling and trismus, followed by the discomfort during the healing phase are the main complaints mentioned in scientific studies ${ }^{11,14-18}$. The same way that the nonsteroidal antiinflammatory drugs (NSAIDs), with common use in surgical practice, the LLLT promotes the same results, however without the side effects. It is worth mentioning that, for immuno-impaired individuals, such as people with diabetes, the benefits described by this therapy are more significant, for they present the same tissue response, also in adverse conditions ${ }^{13}$.
Continuous Emission

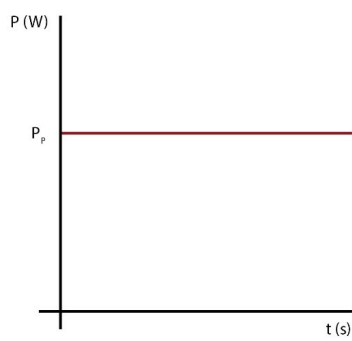

Pulsed Regime

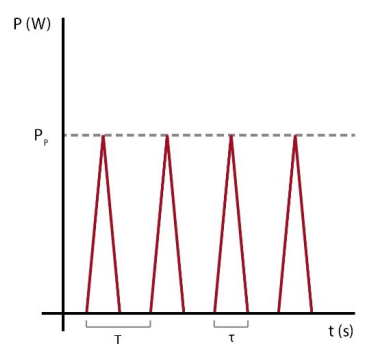

Figure 1. Graphical representation of laser emission types.

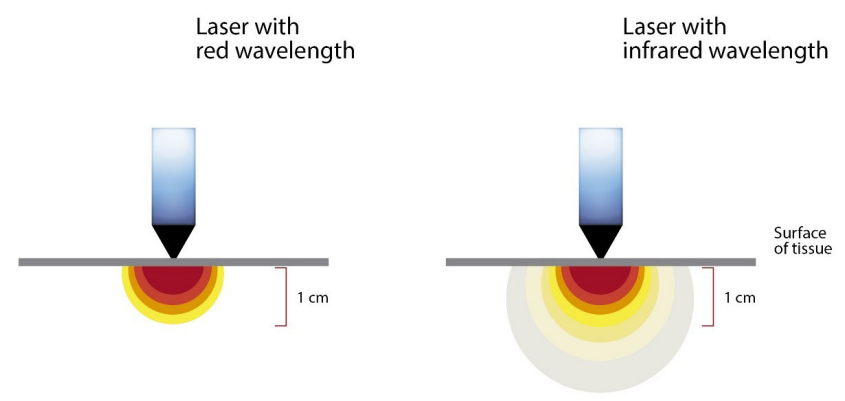

Figure 2. Illustrative scheme exemplifying the penetration of the laser into the tissue according to wavelength.

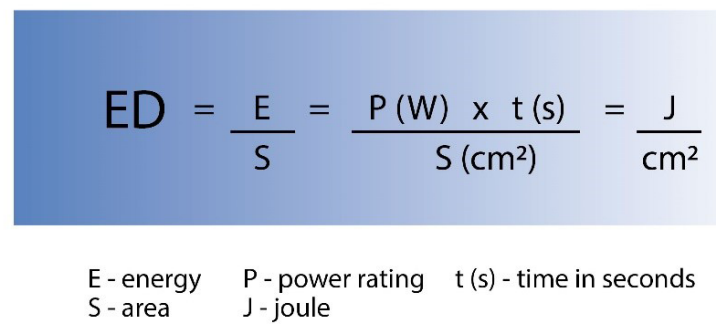

Figure 3 . Energy density formula (ED) 


\section{DISCUSSION}

This review analyzed the use of low-level laser therapy as an influencer in the postoperative phase in SETMs. Although the available studies present benefits for its use, it was noticed the lack of standardization for the irradiation parameters of this therapy.

A review performed in 20118 with 22 scientific papers, with approaches in vitro and in vivo, evaluated the anti-inflammatory action of the low-level laser in the repair of wounds and a difference in patterns was verified. In this analysis, the doses used in humans were of 1,8; 5,$0 ; 8,7$ and $16 \mathrm{~J} / \mathrm{cm}^{2}$ (ED) and wavelengths between 632,8 and $904 \mathrm{~nm}$, this variety in the parameters made the comparison of results more difficult. Nevertheless, there was a positive conclusion on the anti-inflammatory efficiency in the healing initial processes; however, different doses have produced similar physiological results ${ }^{8}$.

In another narrative review ${ }^{11}$, the laser therapy effect was evaluated in 12 studies, reinforcing its usage to reach ideal therapeutic effects in oral surgeries, especially for impacted third molars. Of these, only three were benefic considering the laser use, essentially following the same irradiation parameters ${ }^{11}$. As an example, a clinical monitoring ${ }^{19}$ with 24 patients that presented positive effects with GaAlAs lasers for the control of postoperative trismus, with parameters in $670 \mathrm{~nm}(\lambda), 30 \mathrm{~mW}(\mathrm{cW})$ and total irradiation around $12 \mathrm{~J}\left(4 \mathrm{~J} / \mathrm{cm}^{2}\right)$ of energy ${ }^{19}$. Thus, the review presented controversial results due to the diversity of variables found, such as impaction degree, length of surgery, and mainly the irradiation parameters and dosimetry ${ }^{11}$.

Two clinical trials performed in the cities of Cairo ${ }^{20}$ and Belgrade ${ }^{21}$ with 180 patients compared the analgesia in the postoperative phase with the use of LLLT and the preoperative medical use of $100 \mathrm{mg}$ of diclofenac sodium (NSAIDs). Their irradiation regimes used were similar: $\lambda 870$ and $637 \mathrm{~nm}$, with $4 \mathrm{~J} / \mathrm{cm}^{2}$ (ED) for both studies and constant power with 80 and $50 \mathrm{~mW}$, using the near infrared laser type (GaAlAs) with intraoral placement 10 minutes after the procedure with one centimeter of distance ${ }^{20-21}$. The results of these studies have shown a decrease in the pain intensity in patients who were treated with laser therapy in comparison to the ones treated only with medication. Moreover, it was suggested the possibility that one dose of energy lower than $4 \mathrm{~J} /$ $\mathrm{cm}^{2}$ would not significantly influence the postoperative analgesia ${ }^{21}$.
In Tehran University of Medical Sciences ${ }^{17}$ a research done in 2012 evaluated 100 patients under the effects of diode type laser in the control of the postoperative pain, through a double-blinded randomized clinical trial divided in two groups (laser and irradiation with no control). The dosimetry used was of $810 \mathrm{~nm}(\lambda), 100 \mathrm{~mW}$ (cW) and $4 \mathrm{~J} /$ $\mathrm{cm}^{2}$ of energy, not escaping from the standards mentioned previously ${ }^{16}$. Likewise, other clinical studies performed in Mexico ${ }^{15}$ and in Barcelona ${ }^{22}$, evaluated the effectiveness in the control of pain, swelling and trismus. Such researches presented positive effects with the use of LLLT in the recovery of patients, although with no relevant differences, emphasizing its use as a support in the treatment. However, one of the projects ${ }^{15}$ pointed out that in the need for rescue medication, patients who did not receive laser therapy had less solicitation time.

A systematic review and meta-analysis surveyed randomized and aleatory clinical trials that evaluated the effects of any type of laser therapy in patients that underwent SETMs. The study included 10 trials published in the period from 1990 to 2011, with 581 patients evaluated with the goal to answer whether the adjuvant use of laser was efficient or not for such complications ${ }^{23}$. There were no restrictions regarding the patients characteristics, type or administration regime of LLLT and of the measuring methods of the results. The irradiation parameters were varied, with wavelengths in 632,8; 810; 829 and $830 \mathrm{~nm}$, constant powers in $8 ; 10 ; 30 ; 36$ and $100 \mathrm{~mW}$ and energy doses in $4 ; 10 ; 11,3 \mathrm{~J} / \mathrm{cm}^{2}$.

Such meta-analysis ${ }^{23}$ stood out for being the first broad review on the subject. However, the number of patients who were evaluated did not represent great expressiveness, in comparison to the number of people who go through this type of procedure every year. From the results, it was suggested that the laser therapy used in these studies was not efficient to reduce the pain state and the swelling, but it was benefic to minimize the trismus ${ }^{23}$.

Confronting the former review, a clinical trial performed in Croatia in $2013^{17}$ evaluated 150 patients comparing LLLT with antimicrobial photodynamic therapy (PDT) after the removal of third molars, with aleatory division in three groups (LLLT, $\mathrm{n}=50$; PDT, $\mathrm{n}=50$ and control, $\mathrm{n}=50)^{17}$. In the PDT group, after suture, the photosensitive substance named toluidine chloride (155 $\mu \mathrm{g} / \mathrm{ml}$ ) was applied in the surgery area. After 60 seconds, the region was washed with saline solution and irradiated for 60 seconds ( $2 \times 30$ seconds) with laser of $660 \mathrm{~nm}(\lambda), 90$ $\mathrm{mW}$ (cW) and $5 \mathrm{~J} / \mathrm{cm}^{2}$ (ED) with application of 180 seconds 
( 2 x 90 seconds). The authors concluded that the PDT presented better results, and both groups that received laser therapy did not present complications during the healing phase, oppositely from the control group. Moreover, it was shown that the use of a laser therapy could reduce the use of analgesics by patients in the postoperative phase ${ }^{17}$.

From the lack of standardization in the methods and parameters found in literature, a randomized clinical trial, controlled and double-blinded, was performed in São Bernardo do Campo in $2013^{18}$, aiming to compare four different parameters of LLLT irradiation facing the clinical picture. Such research used the diode laser GaAIAs with power in $100 \mathrm{~mW}(\mathrm{cW})$ and total energy in $12 \mathrm{~J}$, with application in the final moment of surgeries in two types of sites during 30 seconds/point (4 points), where 60 patients were divided in five groups (laser $\lambda 660 \mathrm{~nm}$ with intraoral application; laser $\boldsymbol{\lambda} 808 \mathrm{~nm}$ with intraoral application; laser $\lambda 660 \mathrm{~nm}$ with extraoral application; laser $\lambda 808 \mathrm{~nm}$ with extraoral application; and control group $)^{18}$.

The research revealed some partial results bringing the outcome regarding the pain picture of the treatment ${ }^{24}$. The evaluations were performed on the second and seventh day after the procedure, through the visual analog scale (VAS) and numerical rating scale of 101 points (NRS-101)24. These scales were greatly used in studies to measure pain, being VAS more commonly used in the postoperative phase of SETMs ${ }^{15,18,22-24}$. Considering the intragroup analysis of the studied mentioned above, all of those who received the irradiation presented significantly reduction between the second and the seventh day after the surgery, except for the extraoral red laser group (660 nm). However, from the results among the groups, in any of the scales to measure the postoperative pain, none of the irradiation parameters presented great differences from the control group ${ }^{24}$.

From the findings in literature for our review, it was defined a table (Table 1) with the most used dosimetries.

Table 1. Means and standard deviations for number of fibroblasts, in terms of root fragment conditioning and evaluation time.

\begin{tabular}{|c|c|c|c|}
\hline & $\lambda(\mathrm{nm})$ & Cw (mW) & ED $\left(\mathrm{J} / \mathrm{cm}^{2}\right)$ \\
\hline Piva et al. ${ }^{8}$ & $632,8-685$ & un & un \\
\hline Fekrazad et al. ${ }^{11}$ & 880 & 100 & 4 \\
\hline \multirow[t]{2}{*}{ Jovanic et al. ${ }^{19}$} & 670 & 30 & 4 \\
\hline & 880 & 100 & un \\
\hline Shenawy et al. ${ }^{20}$ & 870 & 80 & 4 \\
\hline Markovic et al. ${ }^{21}$ & 637 & 50 & 4 \\
\hline Saber et al. ${ }^{16}$ & 810 & 100 & 4 \\
\hline Amarillas-Escobar et al. ${ }^{15}$ & 810 & 100 & 4 \\
\hline López Ramirez et al. ${ }^{22}$ & 810 & 100 & 4 \\
\hline Batinjan et al. ${ }^{17}$ & 660 & 90 & 5 \\
\hline Sierra et al. ${ }^{18}$ & 660 e 808 & 100 & un \\
\hline Sierra et al. ${ }^{24}$ & 660 e 808 & 100 & un \\
\hline
\end{tabular}

Note: Note: $\lambda$ - wavelength; cw - continuous emission; ED - energy density; un - uninformed.

\section{CONCLUSIONS}

The recovery of patients who underwent the extraction of third molars, in most cases, is followed by complications like pain, swelling and trismus. As an alternative treatment, low-level laser therapy acts on the cell levels of the organism and its use has increased gradually in dentistry, aiming to bring quality of life in the postoperative phase.

The efficiency of LLLT is mentioned by literature in several models of studies, acting as an anti-inflammatory, tissue restorative and softening the use of analgesics. On the other hand, the variety of parameters used leaves a gap on its real effectiveness, considering that the studies attest its efficiency, however as a supporting treatment.

The limitations of the present review include the heterogeneity of the format of the studies available in the literature, with their distinct variables and dosimetries. It is suggested the accomplishment of more broad and longitudinal clinical trials with standardization in the variables and in the irradiation parameters, aiming to favor the real benefits of this therapy.

Based on this review, we suggest the supporting use of diode laser GaAlAs with $810 \mathrm{~nm}(\boldsymbol{\lambda}), 100 \mathrm{~mW}$ of 
constant power and $4 \mathrm{~J} / \mathrm{cm}^{2}$ of energy, in the intra and extraoral forms, in at least three moments, in the surgery after the suture, in 48 and 72 hours to minimize possible occurrences from surgery of third molars. This suggested dosimetry presents positive results in works with high level of scientific evidence.

\section{REFERENCES}

1. Susarla SM, Blaeser BF, Magalnick D. Third molar surgery and associated complications. Oral Maxillofac Surg Clin North Am. 2003:15(2):177-86.

2. Andrade VC, Rodrigues RM, Bacchi A, Coser RC, Bourguignon Filho AM. Complicações e acidentes em cirurgias de terceiros molares: revisão de literatura. Saber Cient Odontolog. 2012;2(1):27-44.

3. American Association of Oral and Maxillofacial Surgeons. Evidence based third molar surgery. Illinois: American Association of Oral and Maxillofacial Surgeons; 2011.

4. Brugnera Júnior A, Ladalardo TCCGP, Cruz FM. Introdução. In: Brugnera Júnior A, Santos AECG, Bologna ED, Ladalardo TCCGP. Atlas de laserterapia aplicada à clínica odontológica. São Paulo: Santos; 2003. p.1-8.

5. Silva DFT, Almeida-Lopes L, Ribeiro MS. Conceitos físicos básicos aplicados à terapia laser de baixa potência. In: Garcez AS, Ribeiro MS, Núñes SC. Laser de baixa potência: princípios básicos e aplicações clínicas na odontologia. Rio de Janeiro: Elsevier; 2012. p.1-13.

6. Foth HJ. Principles of lasers. In: Lackner M. Lasers in chemistry: probing matter. Weinheim: Wiley-VCH; 2008.

7. Mester E, Spiry T, Szende B, Tota JG. Effect of laser rays on wound healing. Am J Surg. 1971 Oct;122(4):532-5.

8. Piva JAAC, Silva VS, Abreu EMC, Nicolau RA. Ação da terapia com laser de baixa potência nas fases iniciais do reparo tecidual: princípios básicos. An Bras Dermatol. 2011; 86(5):947-54. doi: 10.1590/S0365-05962011000500013

9. Sperandio FF, Giudice FS, Corrêa L, Décio Júnior SP, Hamblin MR, Sousa SCOM. Low-level laser therapy can produce increased aggressiveness of dysplastic and oral cancer cell lines by modulation of Akt/mTOR signaling path way. J Biophotonics. 2013 Oct; 6(10):839-47.

10. Studart N. A física na escola. Rev Bras Ens Fis. 2001; 2(2):4-9.

11. Fekrazad R, Chiniforush N, Bouraima SA, Aslani MVM, Zare M, Safari OA. Low level laser therapy in management of complications after intra oral surgeries. J Lasers Med Sci. 2012;3(4):135-40.

12. Karu T. Primary and secondary mechanisms of action of visible to near-IR radiation on cells. J Photochem Photobiol B. 1999;49(1):117.

\section{Collaborators}

TN MILETO, conception and delineation of the theme, writing the manuscript, research and analysis of the data collected. FG AZAMBUJA, delineation of the proposed theme, orientation and critical review for final article approval.

13. Azevedo LH, Ferreira LS, Souza AA. Terapia laser de baixa potência na cirurgia oral. Terapia laser de baixa potência na cirurgia oral. In: Garcez AS, Ribeiro MS, Núñes SC. Laser de baixa potência: princípios básicos e aplicações clínicas na odontologia. Rio de Janeiro: Elsevier, 2012. p.127-34.

14. Grossi GB, Maiorana C, Garramone RA, Borgonovo A, Creminelli $\mathrm{L}$, Santoro F. Assessing postoperative discomfort after third molar surgery: a prospective study. J Oral Maxillofac Surg. 2007;65(5):901-17.

15. Amarillas-Escobar ED, Toranzo-Fernández JM, Martínez-Rider $R$, Noyola-Frías MA, Hidalgo-Hurtado JA, Serna VM, et al. Use of therapeutic laser after surgical removal of impacted lower third molars. J Oral Maxillofac Surg. 2010;68(2):319-24. doi: 10.1016/j. joms.2009.07.037

16. Saber K, Chiniforush N, Shahabi S. The effect of low level laser therapy on pain reduction after third molar surgery. Minerva Stomatol. 2012;61(7-8):319-22.

17. Batinjan G, Zore IF, Rupić I, Jurič IB, Zore Z, Pandurić DG. Assessing health-related quality of life with antimicrobial photodynamic therapy (APDT) and low level laser therapy (LLLT) after third molar removal. J Lasers Med Sci. 2013;4(3):120-6.

18. Sierra SO, Deana AM, Ferrari RAM, Albarello PM, Bussadori SK, Fernandes KPS. Effect of low-level laser therapy on the postsurgical inflammatory process after third molar removal: study protocol for a double-blind randomized controlled trial. Trials. 2013;14:373. doi: 10.1186/1745-6215-14-373

19. Jovanović G, Burić N, Kesić L. Effect of low power laser on postoperative trismus. The J Fac Univ Med Biol. 2004;11(3):136-8.

20. Shenawy HE, Aboelsoud NH, Zaki AA, Zawahry ME, Shaibeta A. Postoperative pain control in patients after lower third molar extraction. J Am Sci. 2010;6(11):1068-72.

22. Marković AB, Todorović L. Postoperative analgesia after lower third molar surgery: contribution of the use of long-acting local anesthetics, low-power laser, and diclofenac. Oral Surg Oral Med Oral Pathol Oral Radiol Endod. 2006; 102:4-8.

23. López-Ramírez M, Vílchez-Pérez MA, Gargallo-Albiol J, ArnabatDomínguez J, Gay-Escoda C. Efficacy of low-level laser therapy in the management of pain, facial swelling, and postoperative trismus after third molar extraction to lower. A preliminary study. Lasers Med Sci. 2012; 27:559-66.

24. Brignardello-Petersen R, Carrasco-Labra A, Araya I, Yanine N, Beyene $J$, Shah PS. Is adjuvant laser therapy is effective for preventing 
pain, swelling, and trismus after surgical removal of impacted mandibular third molars? A systematic review and meta-analysis. J Oral Maxillofac Surg. 2012; 70:1789-801

25. Sierra SO, Deana AM, Bussadori SK, Mota ACC, Motta U, Ferrari RAM, et al. Effect of low-intensity laser treatment on pain after extraction of impacted mandibular third molars: A randomised, controlled, clinical trial. Br J Oral Maxillofac Surg. 2015;53(10):9961000. doi: 10.1016/j.bjoms.2015.09.006

Received on: 16/12/2015

Final version resubmitted on: 3/8/2016

Approved on: 17/11/2016 